\title{
Salmonella Septic Arthritis of the Knee in a Child
}

\author{
Yadav $\mathrm{R}^{{ }^{*}}$, Nachiappan $\mathrm{N}^{1}$ and Yadav $\mathrm{H}^{2}$ \\ ${ }^{1}$ Hospital Tengku Ampuan Rahimah Klang, Malaysia \\ ${ }^{2}$ International Medical University
}

*Corresponding author: Yadav R, International Medical University, Malaysia, E-mail: Yadav@imu.edu.my

Citation: Yadav R, Nachiappan N, Yadav H (2014) Salmonella Septic Arthritis of the Knee in a Child. J Case

Rep Stud 2(6): 601. doi: 10.15744/2348-9820.2.301

Received Date: June 27, 2014 Accepted Date: November 26, 2014 Published Date: December 03, 2014

\section{Introduction}

Infection with Salmonella $\operatorname{sp} p$ can result in a variety of presentations such as enteric fever, septicemia, gastroenteritis, and septic arthritis. The common organisms seen in septic arthritis are Staphylococcus aureus and Streptococci which accounts for about $67 \%$ and 20\% respectively [1-3]. Salmonella spp however is less commonly seen in septic arthritis [1] and it is usually associated with immunosuppression conditions and underlying chronic debilitating diseases such as malignancy, hemoglobinopathy, diabetes mellitus, and HIV [4]. We report a case of septic arthritis in a healthy child caused by Salmonella spp in a hospital. A Similar incidence of salmonella spp arthritis is reported in Africa [5-8].

\section{Case Summary}

A 1 year 3 months old boy was referred to the tertiary hospital from a private medical centre with a low grade fever $\left(38{ }^{\circ} \mathrm{C}\right)$ and unable to walk. There was no history of preceding trauma, no prior surgery, and no history of traveling recently. His immunizations status was normal and he had no prior illness. On admission, his temperature was $38{ }^{\circ} \mathrm{C}$ and his right knee was swollen and tender. Systemic examination was found to be normal and there was no concurrent infection of other sites. Initial X-ray and ultrasound of both knees showed no remarkable changes. Blood investigations showed increased in the white blood cells $\left(7.4 \mathrm{x} 10^{9} \mathrm{~L}\right)$ and raised C-reactive protein $(33 \mathrm{mg} / \mathrm{L})$. He was initially treated with Cloxacillin and Gentamicin in the private medical centre for seven days. Since there was no response to the treatment he was referred to our tertiary hospital for further investigations of the septic arthritis. On admission to the hospital he was noted to have had six to ten episodes of diarrhoea with no associated vomiting. His fever persisted and he was treated symptomatically with an intravenous drip for the diarrhea after admission. The Widal test was negative and the white blood counts increased to $\left(10.15-22.43 \times 10^{9} \mathrm{~L}\right)$ and C-reactive protein increased to $(58.54 \mathrm{mg} / \mathrm{L})$.

The swelling of the right knee increased and he developed a fixed flexion deformity and he refused to bear weight. A repeat ultrasound was done and it showed a right suprapatellar haematoma with an intramuscular component possibly underlying the infection. Arthrotomy washout of the right knee was done under aseptic technique and $40 \mathrm{~mL}$ of straw coloured bloodstained fluid was removed. The synovial fluid was slightly turbid with few pus cells and a cell count of 250 cells $/ \mathrm{mm}^{3}$. Cultures of the synovial tissue yielded Salmonella spp susceptible to Cefuroxime. The blood, stool and urine cultures did not reveal any growth and his full blood picture did not reveal a sickle cell disease. The patients' symptoms improved following surgical drainage. He was given intravenous Cefuroxime for 7 days. Upon discharge, he was prescribed oral Cefuroxime to complete a 6-week course of therapy. He tolerated the therapy and C-reactive protein declined to $13.5 \mathrm{mg} / \mathrm{L}$. He is currently under regular follow up and being reviewed for any permanent sequelae.

\section{Discussion}

The Salmonella groups of bacteria are gram negative bacilli that can affect both humans and animals. The most common species is Salmonella typhi and it is seen in developing countries, and fever is the most common manifestation. It is well known that the infection can spread through the blood stream in any organ with or without suppuration. These infections at metastatic sites usually occur in patients with pre-existing disease such as haemoglobinopathies especially sickle cell disease [9-11].

Septic arthritis of the knee caused by Salmonella spp is rare in children [8]. Salmonella organisms are known to metastasize to other sites causing more than just gastroenteritis and enteric fever, but very few cases have been reported so far [6,7]. In most reported cases, Salmonella septic arthritis is either associated with immunodeficiency or related to endemic area of Salmonella infection [8]. However our patient had no significant illness since birth, nor was he immunocompromised and there was no concurrent infections at other sites that could have attributed to the metastatic infection. Although an organism specific antibiotic in sufficient dosage, decompression of the joint abscess is regarded as the main therapy in many cases we had to do arthrotomy because there was little improvement in symptomatic treatment. It is well known, however that arthrotomy or arthroscopy with lavage is still unresolved [12]. 


\section{Conclusion}

Septic arthritis of the knee caused by Salmonella spp is rare in children. This case illustrates the importance of appropriate antibiotic therapy and adequate surgical drainage to ensure total eradication of the infection. However since gram-negative bacillary arthritis is known for its poorer prognosis compared to gram-positive joint infections [8], the duration of antibiotic therapy in this case was extended to six weeks.

\section{References}

1. Dubost JJ, Soubrier M, De Champs C, Ristori JM, Brussiere JL, et al. (2002) No Changes in the distribution of organisms responsible for septic arthritis over a 20 year period. Ann Rheum Dis 61: 267-9.

2. Shanti M, Sekar U, Sridharan KS (2012) Septic Arthritis of Hip caused by Salmonella typhi: A case report. Case rep infect Dis. doi 10.1155/2012/464527.

3. Wang CL, Wang SM, Yang YJ, Tsai CH, Liu CC (2003) Septic Arthritis in Children: Relationship of Causative Pathogens, Complications and Outcome. J Micro Immun Infect 36: 41-6.

4. Esat U, Krishna R, Feyza UO, Salih S, Ozlem A, et al. (2013) Salmonella enteridis Septic Arthritis: A Report of two Cases. Case Rep Infect Dis. doi $10.1155 / 2013 / 642805$.

5. Graham SM, Molyneux EM, Walsh AL, Cheesbrough JS, Molyneux ME, et al. (2000) Nontyphoidal Salmonella infections of children in tropical Africa. Pediatr Infect Dis J 19: 1189-96.

6. Molyneux E, French G (1982) Salmonella joint infection in Malawian children. J Infect 4: 131-8.

7. Lavy CB, Lavy VR, Anderson I (1995) Salmonella septic arthritis in Zambian children. Trop Doctor 163-6.

8. Molyneux EM, Lavy CBD, Lavy VR, AL Walsh (1998) Septic arthirits. Lancet 35: 1060-1.

9. Ulug M, Celen MK, Geyik MF, Hosogulu S, Ayaz C (2009) Sacroilitis caused by salmonella Typhi. J Infect Developing countries 3: 564-8.

10. Faseela TS, Malli CS, Balakrishnan AK, Gomes L, Nayak N (2010) Salmonella typhi septic arthritis of the hip-A case report. J clini diag res 4: 2308-10.

11. Olut AI, Avcı M, Ozgenç O, Altay T, Coşkuner SA, et al. (2012) Septic arthritis of the hip due to Salmonella typhi in a patient with multiple sclerosis. Mikrobiyol Bul 46: 113-6.

12. Wirtz DC, Marth M, Miltner O, Schneider U, Zilkens KW (2001) Septic arthritis of the knee in adults: treatment by arthroscopy or arthrotomy. Int Orthop 25: 239-41.

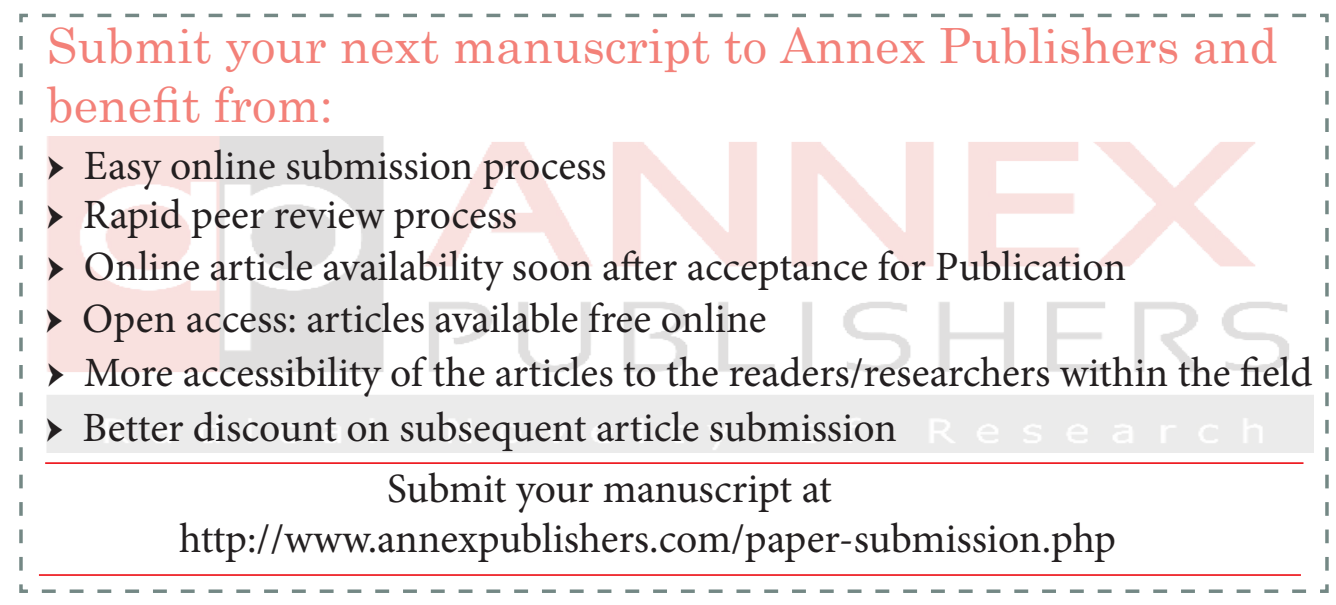

